\title{
Notes on a Poorly Known Blue-Tailed Skink, Eumeces tamdaoensis, from Northern Vietnam
}

\author{
Tsutomu HIKIDA AND ILYA S. DAREVSKY
}

\begin{abstract}
A poorly known skink, Eumeces tamdaoensis is redescribed on the basis of a newly collected specimen from the northern part of Vietnam. The species has been allied to the fasciatus group of the genus 1 Eumeces, but has closer relationship to the East Asian members of the obsoletus group, i.e., E. chinensis and E. kishinouyei.
\end{abstract}

In 1937 Bourret described Eumeces tamdaoensis on the basis of four specimens collected from Tam-dao, northern Vietnam. No additional specimens of this skink have ever been reported thereafter. Two subsequent authors (Fitch, 1958; Lieb, 1985) listed this species as a member of the fasciatus group, which is one of Taylor's (1936) intrageneric groups. However, they did not provide the specific features of this species, probably because they failed to gain access to the original description. Due to unavailability of the publication in which Bourret's (1937) description appeared (i.e., Bulletin Générale de l'Instraction Publique, Hanoi), this species has been one of the least known members of the genus $E \mathbf{E}$ meces.

In 1982 a peculiar specimen of Eumeces was collected from northern Vietnam. Since then we fortunately obtained a copy of Bourret (1937) through the courtesy of Dr. R. Yoshii, and we identified the specimen as E. tamdaoensis, since even details of the morphology of the specimen agreed well with the original description of that species. Although Bourret (1937) compared the species only with $E$. elegans and insufficiently diagnosed it, we found that it is a valid species from comparisons with other East Asian species of Eumeces.

In this paper we redescribe this poorly known species, Eumeces tamdaoensis, Accepted 13, Jul. 1987 based on the newly collected specimen as well as the original description. We further discuss the taxonomic relationship of this species to the other East Asian Eumeces species.

\section{MATERIALS AND METHODS}

Specimen examined.-Eumeces tamdaoensis, ZIL (Zoological Institute of Leningrad) 19806, a male juvenile, collected from Kuk-Fiong, Hasonbinh Province, northern Vietnam (Fig. 1), in July 1982 by I.S. Darevsky.

In describing the scutellation of the

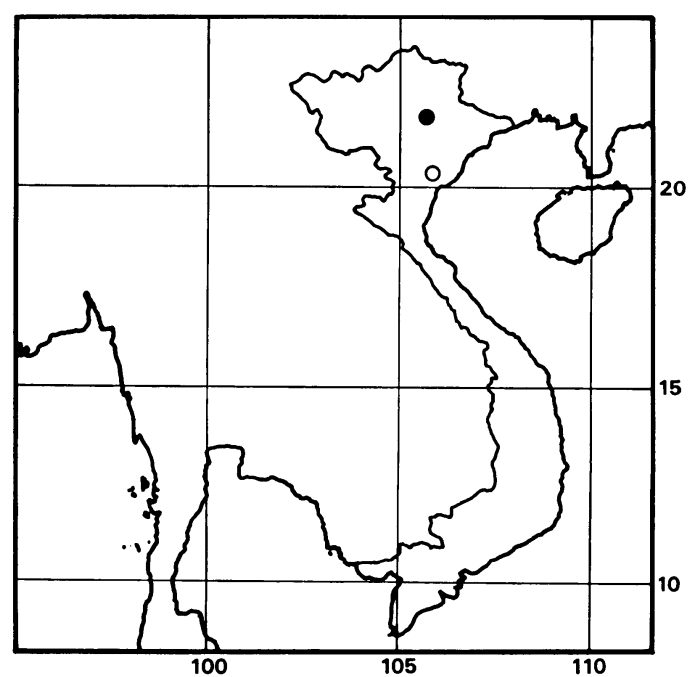

FIG. 1. Known localities of Eumeces tamdaoensis. Closed circle indicates the type locality, Tam-dao, and open circle Kuk-Fiong, Hasonbinh Province, Vietnam. 
head we followed the terminology proposed by Taylor (1936), which is different from that of Bourret (1937); Bourret's 'internasale' and 'postnasale' correspond to Taylor's (1936) postnasal and posterior part of nasal, respectively. Several characters, which we measured or counted here on the present specimen, were not mentioned in the original description of Eumeces tamdaoensis, and therefore provide more detailed description of the species.

\section{Eumeces tamdaoensis Bourret}

1937. Eumeces tamdaoensis Bourret, Bull. Gén. Instr. Publique (Hanoi) 9, p.19, fig. 5, pl. 1 (c, d), (terra typica: Tam-dao, northern Vietnam); 1958, Fitch, Univ. Kansas Publ. Mus. Nat. Hist. 8(1), p.11; 1985, Lieb, Nat. Hist. Mus. Los Angeles County Contr. Sci. (357), p.13.

Four syntypes were reported to be deposited in the Laboratoire des Sciences Naturelles de l'Université Indochinoise, Hanoi (Bourret, 1937), but the present location of these specimens is unknown.

Diagnosis.-A large five-lined and bluetailed skink of the genus Eumeces. Adult with SVL of more than $110 \mathrm{~mm}$. Bifurcating line lacking on parietal region even in juvenile but remaining on snout. Postnasal present. Postmental divided. Nuchals usually two on each side. Lower secondary temporal triangle. Midbody scale rows 22-24. No irregular femoral scale patch. No keels on postanal scales. Paravertebral scales 38-40. Fourth toe subdigitals 17-19.

Description.--Snout rounded, rostral visible above triangular (Fig. 2). Supranasal moderately enlarged, but smaller than prefrontal. Frontonasal large, in contact with anterior loreals. Prefrontal slightly smaller than frontoparietal, in contact with anterior and posterior loreals, first

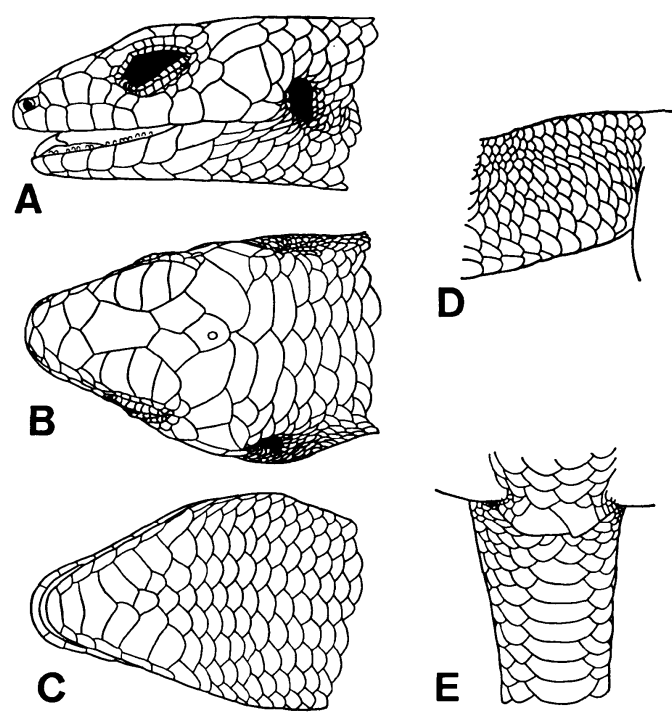

FIG. 2. The fifth specimen of Eumeces tamdaoensis (ZIL 19806) from Kuk-Fiong, Hasonbinh Province, Vietnam. Scutellation of head, femoral, and caudal regions. Lateral (A), dorsal (B) and ventral (C) views of head, and posterior view (D) of right femoral region and caudal region $(\mathrm{E})$.

superciliary and first supraocular, longest suture with frontonasal. Frontal moderate, much longer than its distance from tip of snout, slightly narrower posteriorly, in contact with anterior three supraoculars. Frontoparietals longer than wide, forming a median suture equal to half their length. Interparietal less in area than frontoparietals, round behind, in contact with nuchals, slightly narrowed posteriorly, as long as wide in young, nearly twice as long as wide in adult. Parietal large, greatest width about three fourths of length. Nuchals two pairs. First postnuchal scale in second row slightly larger than following scales. $\mathrm{Na}$ sal moderate, divided, posterior portion behind nostril as large as anterior portion. Postnasal present. Anterior loreal as high as posterior. Posterior loreal three fourths as high as long, touching two supralabials but rarely divided into anterior and posterior part (ZIL 19806, Fig. 2A). Presuboculars two. Supraoculars four. Supercilaries nine. Pre- 
ocular small, followed by small scutes. Postoculars two. Postsuboculars four. Primary temporal large, rectangular, broadly in contact with two secondary temporals. Upper secondary temporal elongated, with sides nearly parallel and posterior edge round. Lower secondary temporal larger in area, posterior end round without notch. Tertiary temporals small, following behind secondary temporals, scarcely differentiated from suprauricular scales. Supralabials eight, composed of five smaller preorbital elements and three larger postorbital. Last supralabial much larger than preceding ones. Lower eyelid with three large plates separated from presuboculars and postsuboculars by two or three rows of granules. Two superimposed postlabials following last supralabial, separating it from ear opening. Two auricular lobules in anterior margin. Mental enlarged with labial border greater than rostral. Postmental divided, posterior larger. Three pairs of chinshields. Enlarged postgenial following third chinshield. Anterior inner edge of postgenial bordered by a scale wider than long. Body scales parallel on side of dorsum, dorsal scales of median row slightly larger than adjoining lateral scales. Scale rows around middle of body $22-24$, normally 24 . Scale rows in constricted portion of neck 26. Paravertebrals 38-40. Subcaudals strongly widened, 9 scale rows encircling tail at level of tenth subcaudal. No keeled scales in postanal region. A median pair of preanals very large, smaller outer scales overlapping inner. Outer wrist tubercle prominent. Finger lamellar formula 6$10-13-13-8$ on left side, $6-11-13-13-8$ on right. Patch of enlarged irregular scales absent on posterior femur. Scales on outer side of sole flat, imbricated. Toe lamellar formula 6-10-15-18-13 on left side and 5-11-15-19-13 on right. Intercalated series of digital scales on only basal phalanx.

Color in preservative.-Color slightly faded in preservative. Dorsum blackish with five strongly defined cream lines (Fig. 3). Median cream line disappears on parietal region, but remains clear on the snout. Dorsolateral lines from first superciliary, running on second and third scale rows from mid line of dorsum. Lateral line beginning on labials, passing back involving lower half of ear-opening and extending back along fifth and sixth scale rows from mid line. Longitudinal region just below lateral line becoming lighter on its lower edge, merging into lighter gray color of side of abdomen. Immaculate cream below. Tail light blue above, lighter below.

Variation.-The measurements and scale counts are shown in Table 1, together with those of syntypes. In the present
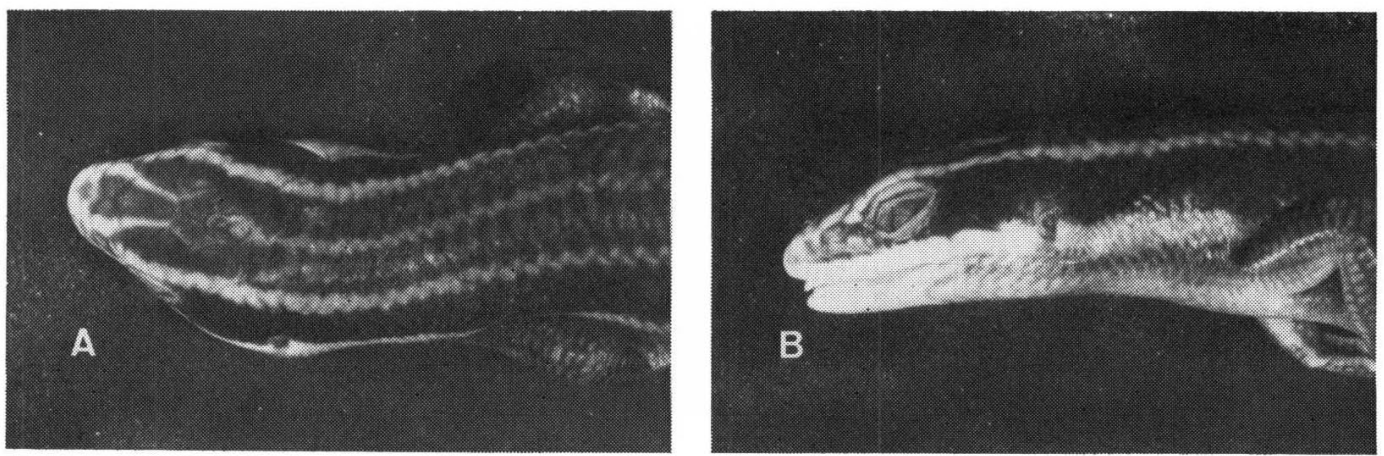

FIG. 3. The fifth specimen of Eumeces tamdaoensis (ZIL 19806) from Kuk-Fiong, Hasonbinh Province, Vietnam. Dorsal (A) and lateral (B) views of head color pattern. 
TABle 1. Measurements $(\mathrm{mm})$ and scutellation (left/right) in five hitherto available specimens of Eumeces tamadoensis.

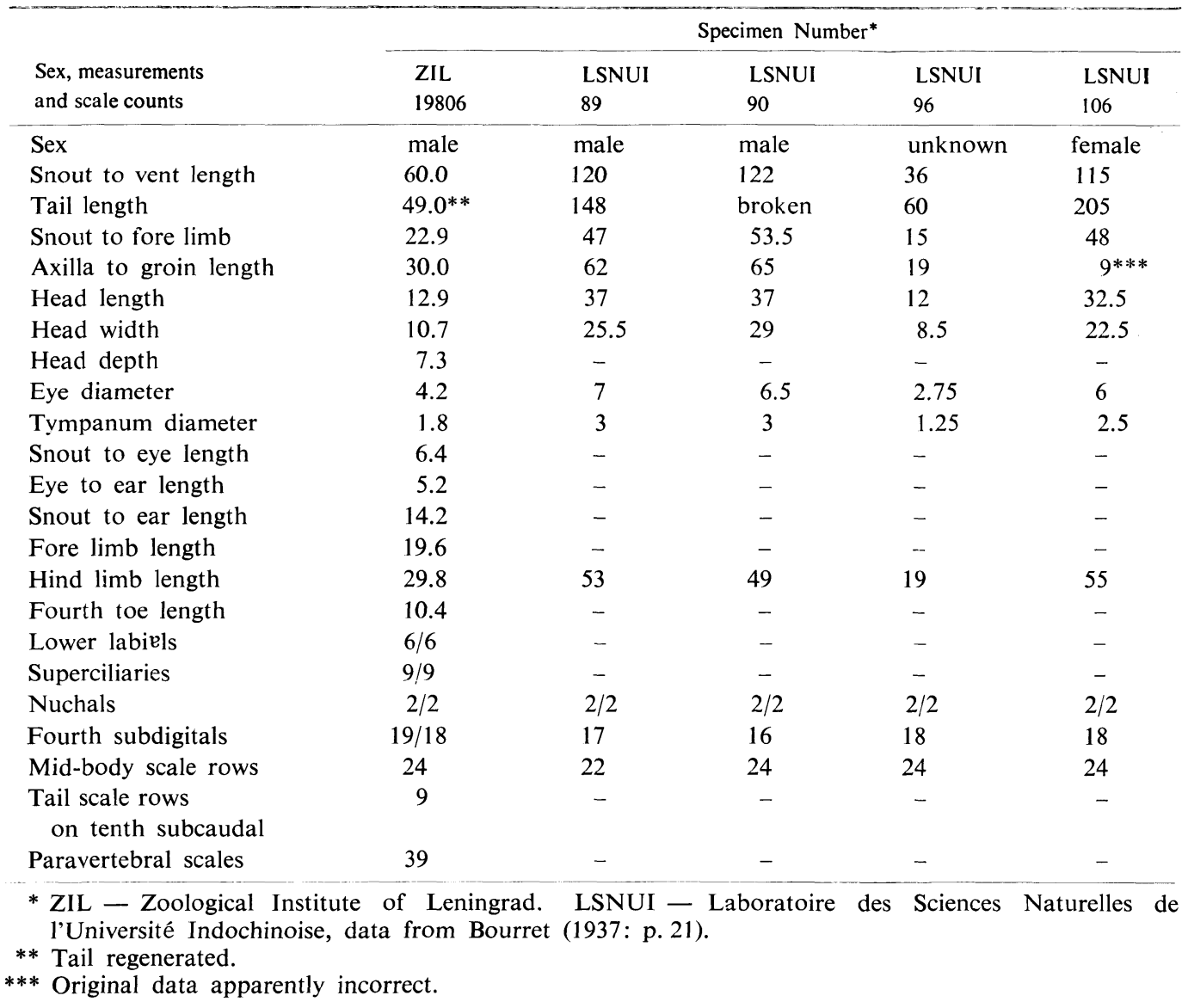

specimen (ZIL 19806) the posterior loreals on both sides were divided into anterior and posterior parts. On the other hand, one of the syntype (LSNUI 89) possessed an undivided posterior loreal (Bourret, 1937: p.20, Fig. 5b). Bourret (1937) did not mentioned this character, but no undivided posterior loreal seems to have been found in the remaining specimens of the type series.

Distribution.-Bourret (1937: p.19) described E. tamdaoensis based on three adults from Tam-dao (Fig. 1) and one juvenile of unknown locality. He, however, suggested that this juvenile specimen had been also captured at Tam-dao.
The present specimen (ZIL 19806) was collected from Kuk-Fiong, which is about $150 \mathrm{~km}$ south of the Tam-dao, and therefore, this species is so far limited to the northern part of Vietnam.

Remarks.-E. tamdaoensis is sympatric with another congeneric species, E. quadrilineatus, one specimen of which was captured from the same locality, KukFiong, by I.S. Darevsky.

\section{Discussion}

Taylor (1936) revised the genus Eumeces and recorded twelve species of three intrageneric groups from East Asia; one species of the quadrilineatus group, 
two species of the obsoletus group and nine species of the fasciatus group. In 1937, just after the publication of his revision, E. tamdaoensis Bourret from Vietnam and E. coreensis Doi and Kamita from North Korea were newly described. Later, E. tamdaoensis was assigned to the fasciatus group (Fitch, 1958; Lieb, 1985). In the comparison of E. tamdaoensis with E. elegans, Bourret (1937) noted that the former differs from the latter in having a postnasal and divided postmentals, and in lacking a bifurcating line on the parietal region. He, however, neither compared E. tamdaoensis with the remaining congeneric species from East Asia, nor mentioned its phylogenetic position.

Eumeces tamdaoensis with the five-lined dorsal color pattern apparently differs from the members of the quadrilineatus group having a four-lined pattern. It is also different from the members of the fasciatus group except $E$. xanthi in having a triangular lower secondary temporal and divided postmentals and in lacking a pair of keeled postanal scale. Eumeces xanthi possesses a pair of keeled postanal scales and an irregular femoral scale patch, both of which are absent in $E$. tamdaoensis. The East Asian obsoletus group consists of E. chinensis, E. kishinouyei, and E. coreensis. The last species was assigned to this intrageneric group by Fitch (1955). The states of some characters in E. coreensis remain unknown, since the original description given by Doi and Kamita (1937) is quite inadequate and the location or deposition of the type specimens is unknown. However, E. coreensis is most similar to $E$. chinensis at least in having a large body size (over $100 \mathrm{~mm}$ in adult SVL), divided postmentals, and a triangular loler secondary temporal, and in lacking a pair of postnasals. Therefore, we agree with Fitch's (1954) assignment of this species to the obsoletus group. Eumeces tamdaoensis resembles the Asian mem- bers of the obsoletus group in having a large size (more than $100 \mathrm{~mm}$ in adult SVL), divided postmentals, and a triangular lower secondary temporal, and in lacking a pair of keeled postanal scales or an irregular femoral scale patch. It is most closely related to E. kishinouyei from the Ryukyu Archipelago of Japan in having a pair of postnasals. Thus, although Fitch (1958) and Lieb (1985) allocated E. tamdaoensis to the fasciatus group, it seems more appropriate to assign this species to the obsoletus group. E. tamdaoensis is distinct from the Asiatic members of the obsoletus group in having a unique pattern on the head and fewer paravertebral scales (38-40) as compared with more than 47 in $E$. chinensis and E. kishinouyei.

ACKNowledgments. - We thank Dr. M. Matsui and $\mathrm{Mr}$. H. Ota for critically reading the manuscript. Special thanks are due to Dr. R. Yoshii for providing a valuable reference. He found a reprint of Bourret (1937) in the reprint collection deposited in the Museum National d'Histoire Naturelle (Paris) and copied it for us. Without his help, we could have never identified the specimen.

\section{Literature Cited}

Bourret, R. 1937. Notes herpétologiques sur la Indochine française. Bull. Gén. Instr. Publique (Hanoi) 9: 1-26.

Doi, H. AND Kamita, T. 1937. A new species of Eumeces from West Corea. Zool. Mag. 49(6): 211-215. (in Japanese)

FITCH, H.S. 1955. Habits and adaptations of the Great Plain skink (Eumeces obsoletus). Ecol. Monogr. 25(3): 59-83.

Fiтch, H.S. 1958. Life history and ecology of the five lined skink, Eumeces fasciatus. Univ. Kansas Publ. Mus. Nat. Hist. 8(1): 1-156.

LIEB, C.S. 1985. Systematics and distribution of the skinks allied to Eumeces tetragrammus (Sauria: Scincidae). Nat. Hist. Mus. Los Angeles County Contr. Sci. (357): 1-19.

TAYLOR, E.H. 1936. A taxonomic study of the cosmopolitan scincoid lizards of the genus Eumeces with an account of the distribution and relationships of its species. Kansas Univ. Sci. Bull. 23(1): 1-643.

Department of Zoology, Faculty of Science, Kyoto University, KitashirakawaOiwakecho, Sakyo-ku, Kyoto, 606 JAPAN 
AND Zoological Institute, Academy of Sciences, Leningrad, 199164 USSR

\section{要旨 ベトナム北部産のトカゲ Eumeces}

\section{tamdaoensis について}

疋田 努・イリヤ S.ダレフスキイ ので, 本種について再記載を行った。また, 従 ベトナム北部のタムダオから，1937年に 来fasciatus 群の一員とされていたこのトカ Bourretによって報告されたトカゲ属の 1 種, ゲが, 尖際は obsoletus 群と近縁であること Eumeces tamdaoensis は, 原記載後なんの報 がわかった。

告も採集例もなく，しかも原記載の論文の入手 が非常に困難なため, 謎につつまれたトカゲと なっていた。このほど，原記載を入手し，さら にベトナム北部から新たに一個体の標本を得た

（606 京都市左京区北白川追分町 京都大学理 学部動物学教室・ソビェト連邦レニングラード 199164 ソビェト連邦科学院レニングラード動 物学研究所) 